\title{
RAINWATER AS A ALTERNATIVE SOURCE OF WATER SUPPLY IN BUILDING - MEASUREMENTS AND EVALUATION
}

\begin{abstract}
There are many water sources available on building sites that can be use as a alternative water sources for supplement the more traditional water sources. These water sources are usually suitable for non-potable purposes and vary greatly in quality so that the most of the on-site water resources have limited application and of course are never suitable for human consumption. Rainwater harvesting appears to be one of the most promising alternatives for supplying freshwater in the face of increasing water scarcity and escalating demand. Advantage of the rainwater harvesting is availability in the most places over the world and that rainwater usually is one of the purest waters available of all the alternate water sources. Submitted paper contains an overview of the possible rain water use for non-potable purposes in one school buildings as well as a possibility of the rainwater harvesting for buildings in TUKE campus as a planned concept for rainwater management.
\end{abstract}

Keywords: efficiency, rainwater, runoff, shaft, water

\section{Introduction}

Concern over stormwater management sustainability has been increasing over the past years also due to climate changes, growing urbanization and unsustainable water management in general thus sustainable practices such as Sustainable Urban Drainage Systems (SUDS), Best Management Practices (BMPs), Low Impact Development (LID), etc. are becoming more and more popular around the world. Rainwater harvesting is not the only part of source control measure in the stormwater management (SWM), it is also the way how to con-

\footnotetext{
${ }^{1}$ Corresponding author: Gabriel Markovič, Institute of Architectural Engineering, Vysokoskolska 4, 04200 Kosice, Slovakia, +00421556024143, gabriel.markovic@tuke.sk

2 Daniela Kaposztásová, Institute of Architectural Engineering, Vysokoskolska 4, 04200 Kosice, Slovakia, + 00421556024143, daniela.ocipova@tuke.sk

3 Zuzana Vranayová, Vysokoskolska 4, 04200 Kosice, Slovakia, zuzana.vranayova@tuke.sk
} 
trol water consumption and how to support qualitative and reasonable water use for different purposes.

One of the objectives of the Water Framework Directive (WFD) is to promote sustainable water use, based on long term protection of available water resources and we can say that rainwater harvesting (RWH) contributes to this objective [1].

Harvesting rainwater and urban stormwater for safe reuse has many potential benefits. It can help to reduce the impact of urban development on water quality and stream flow, and can also help to meet water conservation objectives. Rainwater and stormwater reuse schemes are commonly used in water sensitive design strategies for new urban developments [2]. Systems using alternative water sources are well known in many countries. There are many case studies aimed not only at rainwater and storm water usage, they are concerned in recycling and reuse e.g. of grey water and combined systems of rainwater and grey water or respectively and its reliability and economic effectiveness as $[3,4]$.

\section{Rainwater as a source of potential savings of potable water in TUKE campus}

Buildings types as school, hospitals, offices, commercial premises, rainwater can typically be used for toilets, vehicle washing, yard washdown and watering of plant pots/gardens. In the case of school-type buildings potential of water savings replaced by rainwater is significantly higher. It results from absent of such purposes as showering, bathing (30\%), laundry, etc. as it is at home, so the most volume of potable water is consumed for flushing toilets [5, 6]. Figure 1 represents amount of water demand for purposes typically for commercial premises, schools etc. according to Regulation n. 684/2006 Z. z. Slovak Government Regulation [8].

\begin{tabular}{|c|c|}
\hline average water demand for: & amount \\
\hline flushing toilets & $45 \mathrm{I} /$ person.day \\
\hline cleaning & $6 \mathrm{I} /$ person. day \\
\hline washing & $15 \mathrm{I} /$ person. day \\
\hline irrigation & $60 \mathrm{I} / \mathrm{m} 2$. rok \\
\hline flushing toilet - student & $6 \mathrm{I} /$ student. day \\
\hline flushing toilet - employee & $12 \mathrm{I}$ employee. day \\
\hline washing a car & $200 \mathrm{I} /$ wash \\
\hline
\end{tabular}

Fig. 1. Average water demand according Regulation n. 684/2006 Z. z (SVK) 
Figure 2 represents view of the Technical University of Kosice campus site in Kosice-city. The rectangles indicate school buildings for all faculties of Technical University of Kosice. These buildings have a classical drainage system for rainwater runoff consisting from traditional direct channeling of surface run-off through networks of pipes to sewer system.

But there are two buildings - PK6 and PK5 which have a drainage system for rainwater runoff designed through an infiltration facilities - infiltration shafts. Measured real volumes from PK6 building are shown in chapter 3.

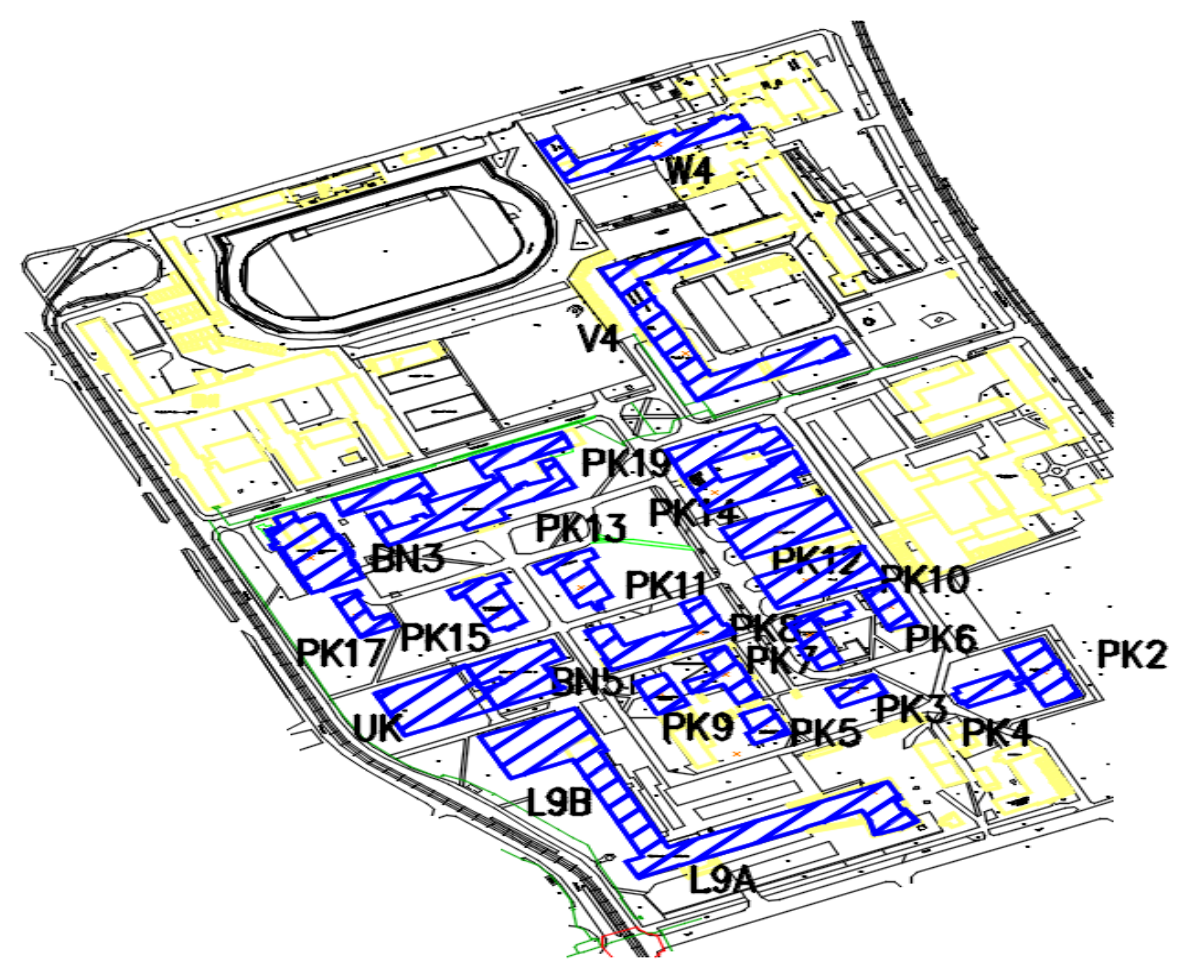

Fig. 2 TUKE campus [9]

A planned situation of rainwater management in TUKE campus considers about the replacing of traditional rainwater drainage into the sewage system by the use of rainwater in the school buildings. All of school buildings respectively the roofs of these buildings in TUKE campus (Fig. 3) represent a potential source of rainwater for non-potable purposes especially for flushing toilets [5]. 


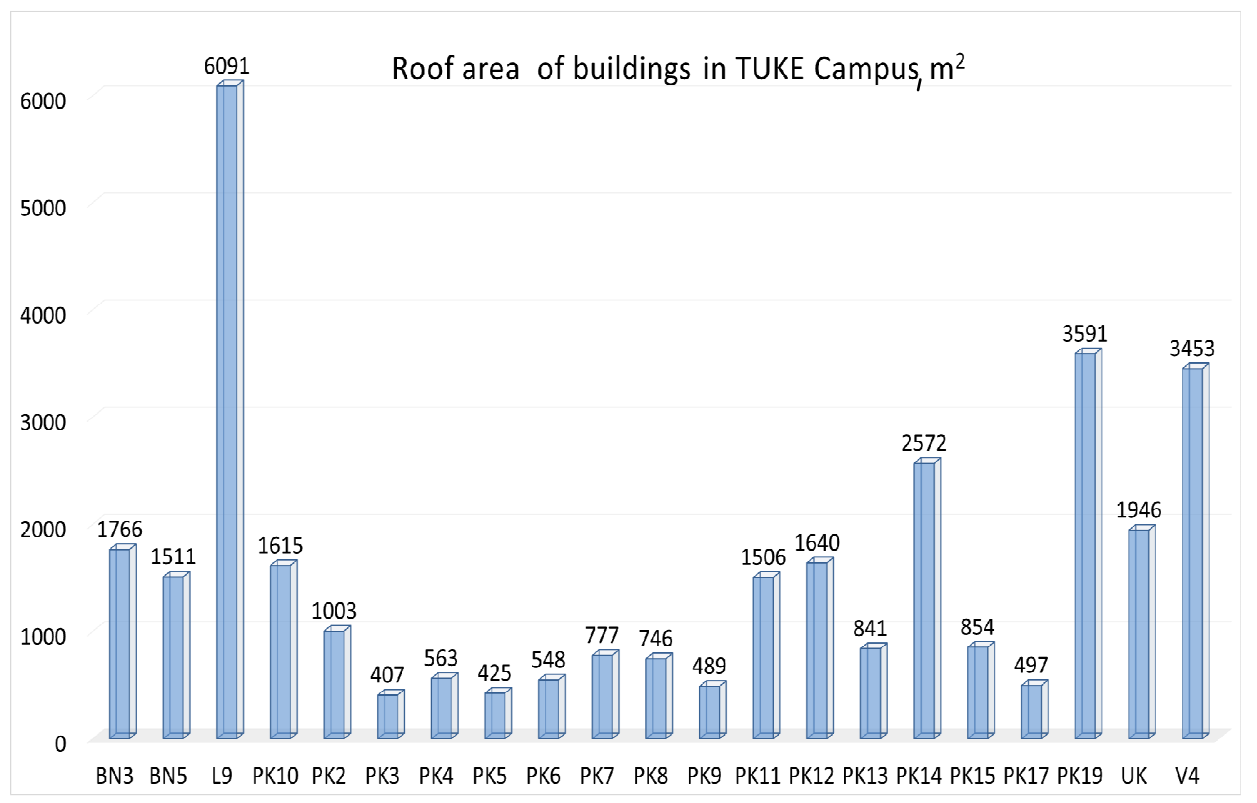

Fig. 3. Roof areas of buildings in TUKE campus as a potential source for RWH

The rooftop area of school buildings (Fig. 1) determine maximum volume of rainwater possible to be captured and accumulated.

Determination of the theoretical volume of rainwater from the catchment's area can be determined by the equation:

$$
V_{\text {rain }}=z_{\text {year }} \cdot A \cdot C
$$

where: $V_{\text {rain }}$ - theoretical volume of rainwater;

$z_{\text {year }}$ - average annual rainfall for chosen locality $(\mathrm{mm})$;

$A$ - roof or another catchment area $\left(\mathrm{m}^{2}\right)$;

$C$ - runoff coefficient (non-dimensional coefficient).

For the determination of theoretical volume of rainwater we need also data of rainfall intensity. The resource, that provide us information about the rainfall intensity is rain gauge and is located on the roof of University Library. Rain gauge is joined with its own concrete foundation using a steel rod. Flat roof helps to fix the rain gauge into horizontal position which is the first condition for receiving correct data. We use recording heated rain gauge for year-round measuring. There are known unheated rain gauges as well used for limited part of year when the temperatures aren't so low. Heated rain gauge is used for measuring liquid precipitation (rain) and solid precipitation (snow) as well. Rain gauge is made of stainless material. Rain gauge's adjoining catchment area is $200 \mathrm{~cm}^{2}$ 
and its function is based on tipping bucket mechanism. Tipping bucket is located inside the rain gauge body right under the funnel outlet. Rain or snow fall down the funnel outlet into the divided bucket. The bucket does not move until it is filled with calibrated $0.2 \mathrm{~mm}$ amount of water, then it tips and second half of bucket can be filled with rain water. When the bucket tips it empties the liquid from the half of the bucket into a drainage hole. Tipping bucket is made of plastic with very thin layer of titanium and it is hanged on stainless steel axial holder. Tipping continues according to the length of rainfall [7]. Figure 4 represent the measured monthly rainfall totals during our research. Data are presented for the period of August 2011 to December 2015.

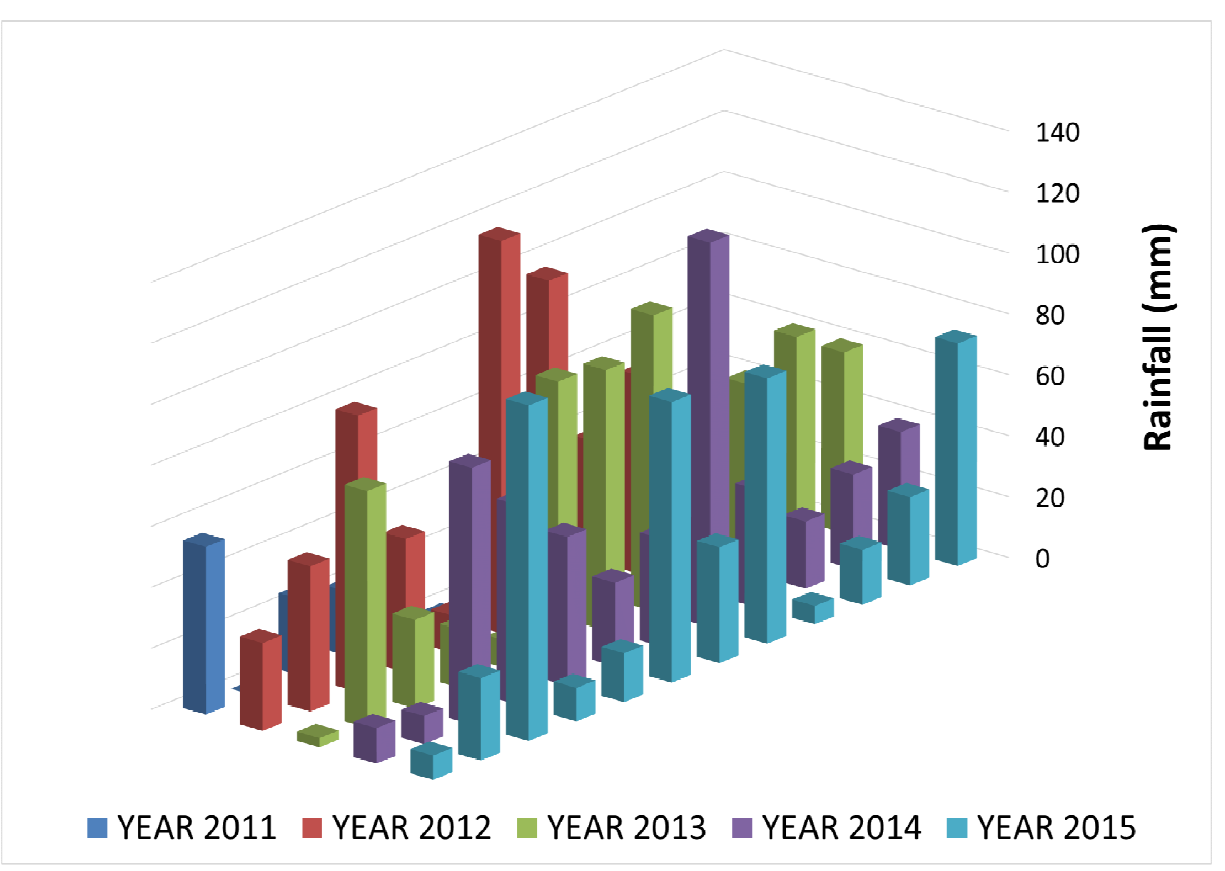

Fig. 4. Measured values of rainfall during our research (August 2011-December 2015)

According to our measurements of monthly rainfall totals, Figure 5 represent theoretical monthly volumes of collected rainwater from roof areas of buildings in TUKE campus. Data are presented for the period of August 2011 to December 2015.

\section{Rainwater as a source of potential savings of potable water in TUKE campus - building PK6}

We have started our research and own measurements in scope of stormwater quantity and quality parameters at the campus of Technical University of 
Košice within the project relating to the management of stormwater. The objects of research represent two infiltration shafts in the campus of TU Kosice that were made before the start of our research. These infiltration shafts represent drainage solution for real school building PK6 and all of the runoff rainwater falling onto the roof flows into these underground shafts $[8,9]$. Data of rainwater inflow provide us the information about real rainwater volumes from roof construction of PK6 building.

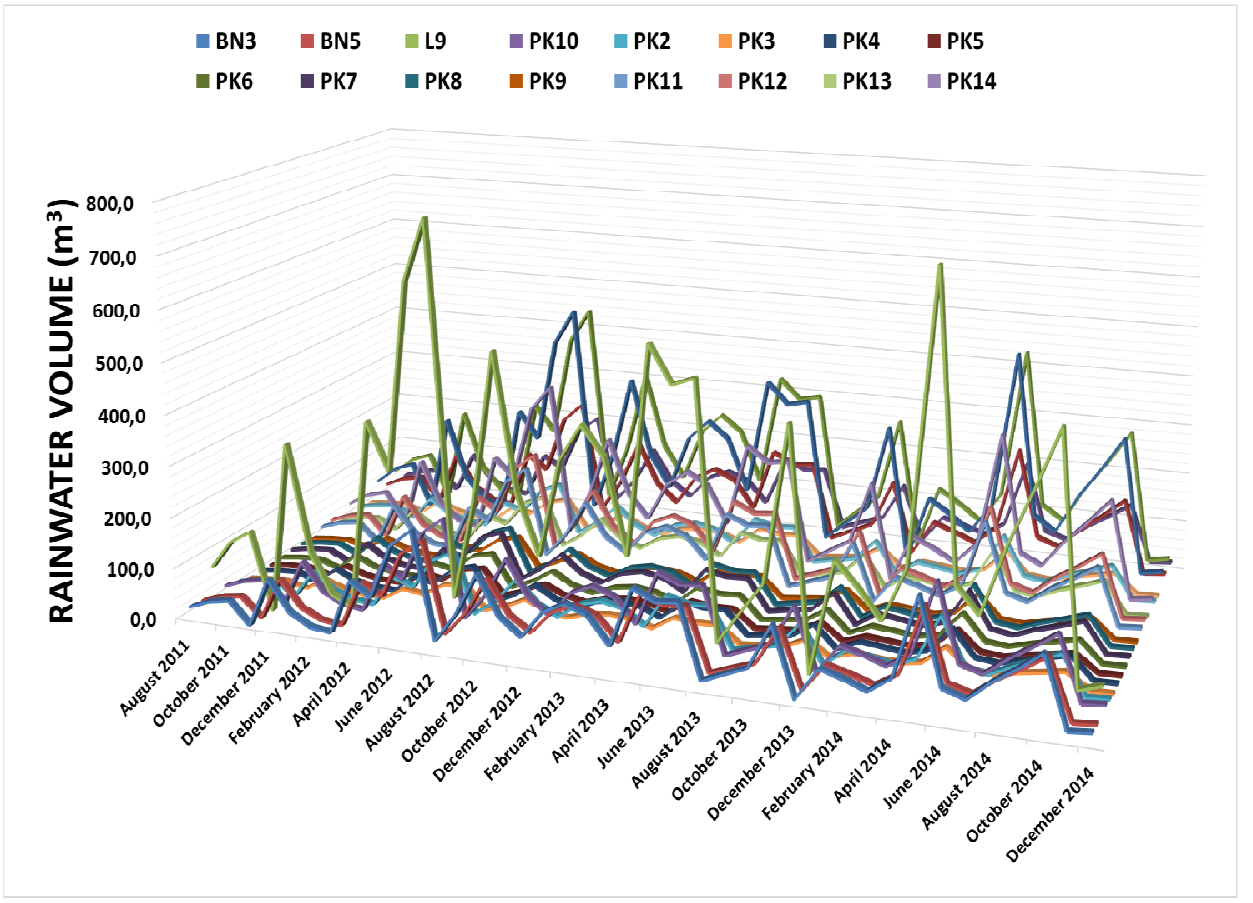

Fig. 5. Theoretical monthly volumes of collected rainwater from roof areas of buildings in TUKE campus during our research August 2011 - December 2015 (based on [9])

Table 1 summarizes the measured monthly rainfall totals with corresponding theoretical volumes of collected rainwater and comparison with real volumes of collected rainwater from our measurements. Data are presented for the period of April 2012 to December 2015 (data are present from April 2012 because at that time it was started the measuring of the flow from all roof area of the building PK6 and precipitation measurements simultaneously) (Notice: August 2012 without data due to equipment failure) [11]. 
Rainwater as a alternative source of water supply...

Table 1. Measured monthly rainfall totals with corresponding theoretical volumes of collected rainwater and real amount of rainwater from roof of PK6 building $\left(548 \mathrm{~m}^{2}\right)$

\begin{tabular}{|c|c|c|c|}
\hline Month & Rainfall (mm) & $\begin{array}{l}\text { Theoretical volume } \\
\text { from } 548 \mathrm{~m}^{2}\left(\mathrm{~m}^{3}\right)\end{array}$ & $\begin{array}{c}\text { Real volume from } \\
548 \mathrm{~m}^{2}\left(\mathrm{~m}^{3}\right)\end{array}$ \\
\hline April 2012 & 65 & 35,6 & 26,7 \\
\hline May 2012 & 50 & 27,4 & 18,9 \\
\hline June 2012 & 109 & 60,0 & 40,8 \\
\hline July 2012 & 129 & 70,6 & 49,6 \\
\hline August 2012 & 12 & 6,7 & - \\
\hline September 2012 & 44 & 24,0 & 17,9 \\
\hline October 2012 & 91 & 49,6 & 36,5 \\
\hline November 2012 & 48 & 26,1 & 16,9 \\
\hline December 2012 & 29 & 15,8 & 12,1 \\
\hline January 2013 & 59 & 32,6 & 19,9 \\
\hline February 2013 & 71 & 38,8 & 23,5 \\
\hline March 2013 & 62 & 33,8 & 22,8 \\
\hline April 2013 & 32 & 17,6 & 11,8 \\
\hline May 2013 & 97 & 53,2 & 30,6 \\
\hline June 2013 & 85 & 46,8 & 30,2 \\
\hline July 2013 & 88 & 48,2 & 36,6 \\
\hline August 2013 & 9 & 4,9 & 3,8 \\
\hline September 2013 & 19 & 10,5 & 8,9 \\
\hline October 2013 & 29 & 15,9 & 13,7 \\
\hline November 2013 & 78 & 42,5 & 38,4 \\
\hline December 2013 & 3 & 1,6 & 1,3 \\
\hline January 2014 & 39 & 21,2 & 10,9 \\
\hline February 2014 & 31 & 17,0 & 12,4 \\
\hline March 2014 & 22 & 12,1 & 8,3 \\
\hline April 2014 & 39 & 21,3 & 13,3 \\
\hline May 2014 & 126 & 69,2 & 44,9 \\
\hline June 2014 & 35 & 19,4 & 12,6 \\
\hline July 2014 & 27 & 15,0 & 13,9 \\
\hline August 2014 & 49 & 26,7 & 20,8 \\
\hline September 2014 & 66 & 35,9 & - \\
\hline October 2014 & 84 & 46,1 & - \\
\hline November 2014 & 9 & 5,0 & 4,1 \\
\hline December 2014 & 12 & 6,4 & 4,7 \\
\hline January 2015 & 73 & 40,0 & 22,9 \\
\hline February 2015 & 29 & 15,9 & 8,9 \\
\hline March 2015 & 18 & 9,9 & 4,8 \\
\hline April 2015 & 6 & 3,3 & 2,1 \\
\hline May 2015 & 87 & 47,7 & 19,9 \\
\hline June 2015 & 38 & 20,8 & 11,0 \\
\hline July 2015 & 92 & 50,5 & 23,3 \\
\hline August 2015 & 16 & 8,8 & 3,9 \\
\hline September 2015 & 11 & 6,0 & 4,1 \\
\hline October 2015 & 110 & 60,3 & 35,6 \\
\hline November 2015 & 27 & 14,8 & 7,9 \\
\hline December 2015 & 8 & 4,4 & 2,2 \\
\hline
\end{tabular}


Another step of our research was to compare the current total consumption of potable water in PK6 building with volume of rainwater runoff from the roof which represents a potential source of water in PK6 building.

Table 2 represents real volumes of rainwater from $548.55 \mathrm{~m}^{2}$ roof of PK6 building and comparison with total consumption of potable water use for every activities in this building measured during 2014-2015. (Note 1: September and October 2014 without data due to equipment failure, Note 2: data of total consumption of potable water are aviable only from year 2014).

Table 2. Measured values of rainwater from PK6 building with comparison to total consumption of potable water in this building

\begin{tabular}{|l|c|c|c|}
\hline Month & $\begin{array}{c}\text { Real volume } \\
\text { from } \\
\mathbf{5 4 8 , 5 5} \mathbf{~ m}^{\mathbf{2}}\left(\mathbf{m}^{\mathbf{3}}\right)\end{array}$ & $\begin{array}{c}\text { Total consumption of } \\
\text { potable water in PK6 } \\
\text { building }\left(\mathbf{m}^{\mathbf{3}}\right)\end{array}$ & $\begin{array}{c}\text { Excess/lack } \\
\text { of water } \\
\left(\mathbf{m}^{\mathbf{3}}\right)\end{array}$ \\
\hline January 2014 & 10,9 & - & $\mathbf{1 0 , 9}$ \\
\hline February 2014 & 12,4 & 6,0 & $\mathbf{6 , 4}$ \\
\hline March 2014 & 8,3 & 18,0 & $-9,7$ \\
\hline January 2015 & 13,3 & 14,0 & $-0,7$ \\
\hline May 2014 & 44,9 & 14,0 & $\mathbf{3 0 , 9}$ \\
\hline June 2014 & 12,6 & 15,0 & $-2,4$ \\
\hline July 2014 & 13,9 & 9,0 & $\mathbf{4 , 9}$ \\
\hline August 2014 & 20,8 & 6,0 & $\mathbf{1 4 , 8}$ \\
\hline September 2014 & - & 4,0 & - \\
\hline October 2014 & - & 11,0 & - \\
\hline November 2014 & 4,1 & 23,0 & $-18,9$ \\
\hline December 2014 & 4,7 & 17,0 & $-12,3$ \\
\hline January 2015 & 22,9 & 8 & $\mathbf{1 4 , 9}$ \\
\hline February 2015 & 8,9 & 11 & $-2,1$ \\
\hline March 2015 & 4,8 & 13 & $-8,2$ \\
\hline April 2015 & 2,1 & 10 & $-7,9$ \\
\hline May 2015 & 19,9 & 23 & $-3,1$ \\
\hline June 2015 & 11,0 & 12 & $-1,0$ \\
\hline July 2015 & 23,3 & 9 & $\mathbf{1 4 , 3}$ \\
\hline August 2015 & 3,9 & 3 & $\mathbf{0 , 9}$ \\
\hline September 2015 & 4,1 & 9 & $-4,9$ \\
\hline October 2015 & 35,6 & 7 & $\mathbf{2 8 , 6}$ \\
\hline November 2015 & 7,9 & 8 & $-0,1$ \\
\hline December 2015 & 2,2 & 31 & $-28,8$ \\
\hline
\end{tabular}




\subsection{Quality of collected rainwater from building PK6}

Measurements of qualitative parameters ( $\mathrm{pH}$ and conductivity) by multiparameter water sensor started at the end of 2011. Multiparameter water sensor is situated at measurement flume. The $\mathrm{pH}$ and conductivity values are being measured continually. Monthly average values of $\mathrm{pH}$ and conductivity from years 2013-2014 are depicted on the Figures 6-9 [5, 9].

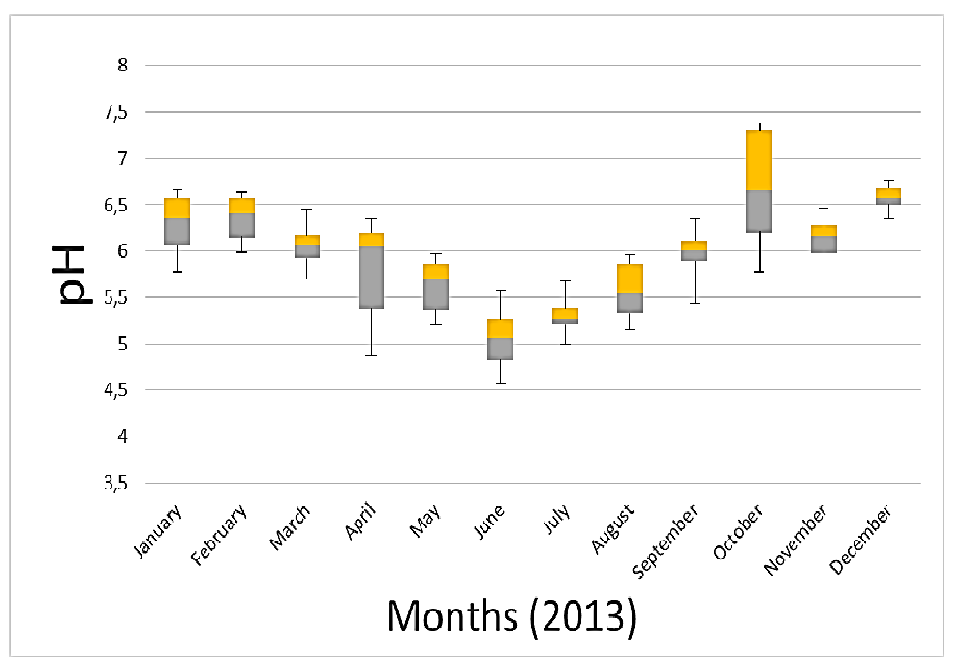

Fig. 6. $\mathrm{pH}$ values of rainwater collected from the PK6 building during 2013

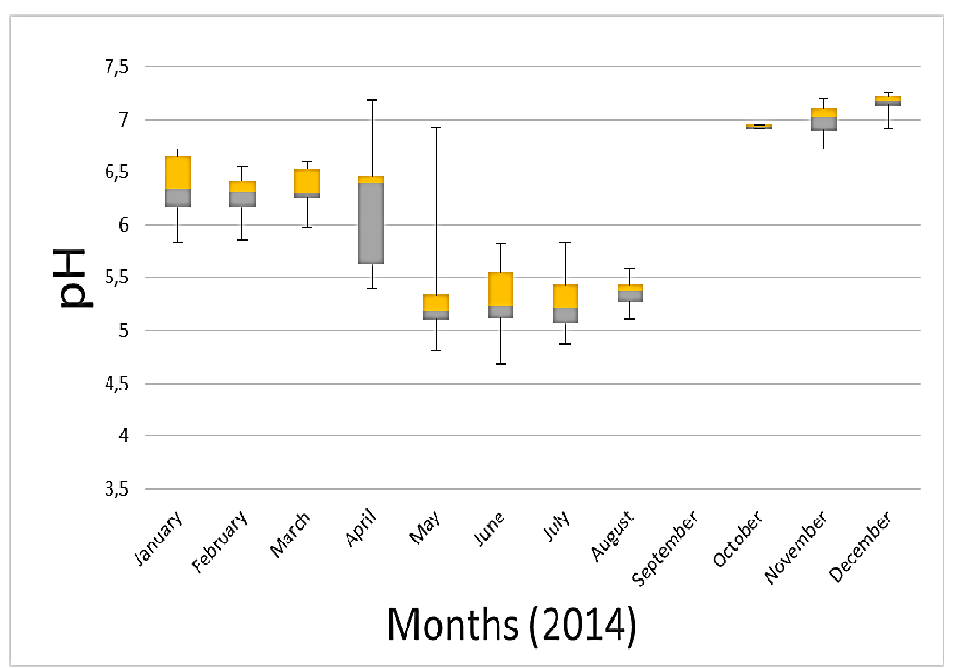

Fig. 7. $\mathrm{pH}$ values of rainwater collected from the PK6 building during 2014 


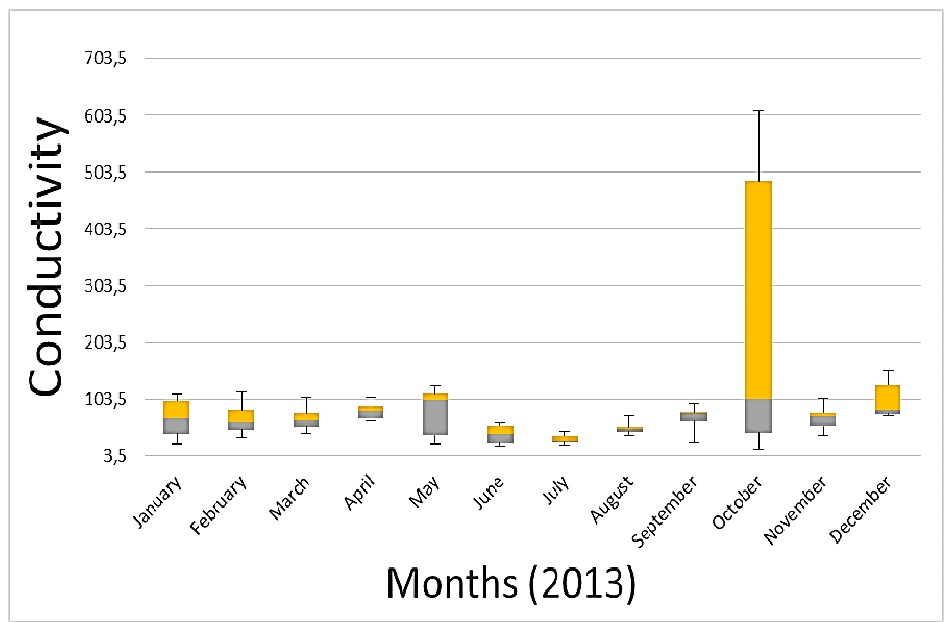

Fig. 8. Conductivity values of the rainwater from the PK6 building during 2013

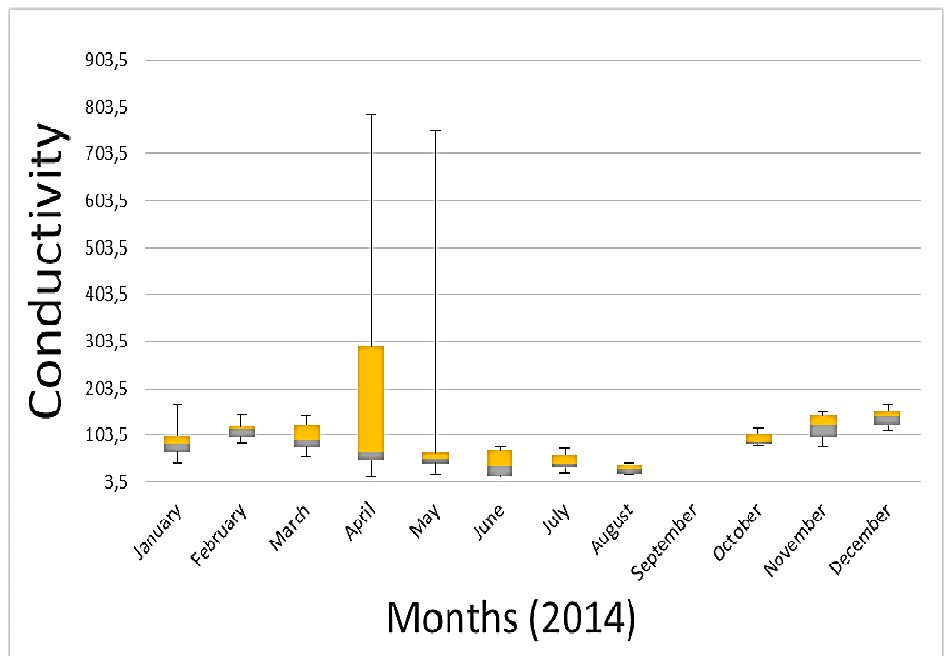

Fig. 9. Conductivity values of the rainwater from the PK6 building during 2014

\section{Conclusion}

Rainwater harvesting consist from the collection of rainwater from rooftops that is then diverted and stored for later use for planned purposes. Captured rainwater is commonly used for non-potable applications and is often used to toilet and urinal flushing, washing clothes, irrigate landscaping or other uses include fountain filling, cooling tower make-up or as a source of fire water.

In generally, rainwater harvesting can help to manage stormwater by reducing the amount of runoff, and may contribute against flooding and erosion by 
slowing runoff or allowing it to soak into the ground. The main goal of rainwater harvesting is of course saving of potable water.

Five years of experiences and measurements show a big potential for savings of potable water by the use of rainwater in the TUKE campus. Results from our measurements show that there are months without full coverage of water demand for PK6 building, but we have to notice excess of collected water against total consumption of water in this building. Rainwater is one of the purest waters available of all the alternate water sources what was confirmed by our measurements of qualitative parameters. The water is free of salts and other harmful minerals and typically requires minimal treatment. The most of $\mathrm{pH}$ and conductivity data show similar quality as is required on potable water.

\section{Acknowledgement}

\section{This work was supported by the VEGA 1/0202/15 Sustainable and Safe Water Management in Buildings of the 3rd. Millennium}

\section{References}

[1] The Water Framework Directive 2000/60/EC.

[2] National Water Quality Management Strategy, Document No 23, Stormwater Harvesting and Reuse, ISBN 1-921173-45-9, 2009, online: http://www.ephc.gov.au/ sites/default/files/WQ_AGWR_GL_Stormwater_Harvesting_and_Reuse_Final_200 907.pdf \{accessed: April 5, 2010\}.

[3] Ghisi E., Ferreira D. F.: Potential for potable water savings by using rainwater and greywater in a multi-storey residential building in southern Brazil, Building and Environment vol. 42, 2007, pp. 2512-2522.

[4] Ghisi E., Mengotti de Oliveira S.: Potential for potable water savings by combining the use of rainwater and greywater in houses in southern Brazil, Building and Environment vol. 42, 2007, pp. 1731-1742.

[5] Markovič G, Vranayová Z.: Measurements of the quality of rainwater run-off and its potential for savings of potable water in TUKE campus [In:] WSEAS transactions on environment and development, ISSN 1790-5079, vol. 11, 2015, pp. 302-311.

[6] Słyś D.: Potential of rainwater utilization in residential housing in Poland, Water and Environment Journal, vol. 23 Issue 4, pp. 318-325.

[7] Gaňová L., Zeleňáková M., Purcz P., Kuzevičová Ž., Hlavatá H.: A rainfall distribution and their influence on flood generation in the eastern Slovakia [In:] Acta Universitatis Agriculturae et Silviculturae Mendelianae Brunensis, vol. 61, no. 6, 2013, pp. 1645-1652.

[8] Markovič G., Zeleňáková M.: Measurements of quality and quantity of rainwater runoff from roof in experimental conditions [In:] ICITSEM 2014 : International conference on innovative trends in science, engineering and managment 2014: 12th and 13th February 2014, Dubaj, UAE. - [Bangalore]: Mudranik Technologies, ISBN 978-93-83303-19-92014, pp. 145-151. 
[9] Markovič G., Vranayová Z.: Infiltration as a way of surface water drainage, Košice: TU - 2013, 137 s, ISBN 978-80-553-1541-6.

\section{RESEARCH AND EVALUATION OF INFILTRATION SHAFT EFFICIENCY IN REAL CONDITIONS}

\section{S u m m a r y}

Harvesting rainwater and urban stormwater for safe reuse has many potential benefits. It can help to reduce the impact of urban development on water quality and stream flow, and can also help to meet water conservation objectives. Rainwater and stormwater reuse schemes are commonly used in water sensitive design strategies for new urban developments.

Five years of experiences and measurements show a big potential for savings of potable water by the use of rainwater in the TUKE campus. Results from our measurements show that there are months without full coverage of water de-mand for PK6 building, but we have to notice excess of collected water against total consumption of water in this building. Quality of runoff is sufficient for non-potable purposes and the most of $\mathrm{pH}$ and conductivity data show similar quality as is required on potable water.

Keywords: efficiency, rainwater, runoff, shaft, water

DOI:10.7862/rb.2016.164

Przestano do redakcji: 01.05.2016 $r$.

Przyjęto do druku: 28.06.2016 r. 